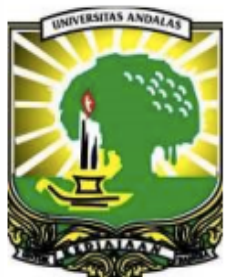

\title{
Fishermen's Behavior of Multi Ethnic Community in Adapting Climate Change in Small Island
}

\author{
Ihsannudin $^{a^{*}}$, Dwi Ratna Hidayati ${ }^{a}$, Aminah H.M Ariyania ${ }^{a}$, Subejo ${ }^{b}$ and Suadi $^{c}$ \\ ${ }^{a}$ Agribusiness Department, Agricultural Faculty Trunojoyo University of Madura \\ ${ }^{b}$ Extension and Development Communication Department, Agricultural Faculty, Gadjah Mada University \\ ${ }^{c}$ Fisheries Department, Agricultural Faculty, Gadjah Mada University
}

\section{A R T I C L E I N F O}

Article history:

Submitted July 2017

Revision received November 2017

Accepted December 2017

Keywords:

Fisherman

Multi ethnic

Small Island

Climate change

\begin{abstract}
A B S T R A C T
In a development perspective, small islands have limited economic access and opportunities, especially related to the economics of scale. Furthermore, the common problem such as climate change impact requires appropriate behavior of local inhabitant in order to survive in gaining to the economic access. Multi-ethnic society has different socio-cultural background that implies special characteristics and strategies to overcome climate change impacts. This study was conducted in Masalembu Island which consist of Madurese, Mandar, Bugis and Javanese ethnic. The aims of this study are to describe negative impact of climate change to the fisherman and to describe fisherman's behavior for adapting climate changes. The analysis method is mixed method between the descriptive quantitative and qualitative analysis. The results show climate change causes fluctuating fish production, extending fishing ground to be more off-shore, uncertainty schedule for fishing and invasion from outer fisherman. Meanwhile, fishermen's behavior in overcoming the impacts of climate change consist of active response by Group of Fishermen, apply autonomous adaptation and apply adaptation behavior technologically, sociologically and regulatory. Based on these results, it is necessary to improve planned adaptation trough aquaculture, applying modern but friendly technology fishing gear and enhancing participation as well as cooperation among fisherman without ethnic consideration.
\end{abstract}

\section{Introduction}

Indonesia consists of series either small and big size islands. Until now there have been 7,870 islands with name, meanwhile more than 9000 islands are still unnamed.

Definition of small islands regulated by Indonesia as mentioned in Ministry Decision of Marine and Fisheries No. 67/2002 is islands with size minimally or equal to $10,000 \mathrm{~km}^{2}$, with population less than or equal to 200,000 peoples. Meanwhile small islands according to The Law number 27 The Year of 2007 About Management of Coastal and Small Islands, small islands mean islands with size less than or equal $2,000 \mathrm{~km}^{2}$ within ecosystems. Those thousands small islands are needed to be utilized optimally in order to support various aspect of development

In point of view of development potential perspective, small islands have limited economic opportunity especially concerning with economic of scale caused by insularity (Briguglio,1995). Due to this, people of small islands are closely related to poverty and economic as well as limited livelihood (Morduch, 1994; Mohanty, 2006; Tisdell, 2006). Most of occupation as fisherman in these small islands is 
highly dependence on nature condition which the support capability keeps decreasing by the time and already overexploitation (Turner, et al, 2014). As description of local case, Muhsoni (2006) explained that demersal fisheries at Madura Strait showed effort optimal (Eopt) reached 75.8962,95 trips/year and total equilibrium production (Cmsy) 24.999,80 tonnes/year and there have been over fishing during last three years.

Indonesia consists of series either small and big size islands. Until now there have been 7,870 islands with name, meanwhile more than 9000 islands are still unnamed.

Definition of small islands regulated by Indonesia as mentioned in Ministry Decision of Marine and Fisheries No. 67/2002 is islands with size minimally or equal to $10,000 \mathrm{~km}^{2}$, with population less than or equal to 200,000 peoples. Meanwhile small islands according to The Law number 27 The Year of 2007 About Management of Coastal and Small Islands, small islands mean islands with size less than or equal $2,000 \mathrm{~km}^{2}$ within ecosystems. Those thousands small islands is potency needed to be utilized optimally in order to support various aspect of development

In point of view of development potential perspective, small islands have limited economic opportunity especially concerning with economic of scale caused by insularity (Briguglio,1995). Due to this, people of small islands are closely related to poverty and economic as well as limited livelihood (Morduch, 1994; Mohanty, 2006; Tisdell, 2006). Most of occupation as fisherman in these small islands is highly dependence on nature condition which the support capability keeps decreasing by the time and already overexploitation (Turner, et al, 2014). As description of local case, Muhsoni (2006) explained that demersal fisheries at Madura Strait showed effort optimal (Eopt) reached 75.8962,95 trips/year and total equilibrium production (Cmsy) 24.999,80 tonnes/year and there have been over fishing during last three years.

This condition had triggered high competitions among fisherman especially in small islands for the fishing result. In addition, recent change on climate condition had worse the situation. Climate change had given threats on food, water provision, increase in the number of people exposed to vectorborne disease, increase in the number of people dying from heat stress, a widespread increase in the risk of flooding for many human seetlement and severe threats to millions of people living on low-lying islands and atolls.
Furthermore, climate change, especially for the small island community that depend on fisheries through multiple pathways (Kasperson and Kasperson, 2001; Ajao and Ogunniyi, 201). Furthermore, Badjeck, et al (2010) stated that changes in water temperature, precipitation and oceanographic variables, such as wind velocity, wave action and sea level rise, can bring about significant ecological and biological changes to marine and freshwater ecosystems and their resident fish populations, directly impacting peoples whose livelihoods depend on those ecosystems.

Furthermore, climate change causes droughts, higher temperatures, flooding, sea-level rise, heat waves, more intense storms, and greater uncertainty in weather patterns translate into more widespread diseases, greater biodiversity loss, crop losses, and system transformations which in turn imply major social and economic dislocations and threats to livelihoods of the poor (Agrawal. 2008).

This condition needs serious handling based on local area and condition. Natural assets with experienced human resource and financial support as well as excellent social relationship are the appropriate option for enhancing coastal fishing community resilience to withstand climate change disaster events (Hossain, et al. 2013). Social economic of institutional and local customs has big role in managing dynamic living of society including climate change adjustment (Subejo, 2008; Suadi dan Nikigawa, 2009).

Multi ethnic community gives implication on difference of social and economic background (Subejo. 2009). Although ethnic difference is fragile to conflict existence that may impede economic and development stability (Suntoo and Chitoo. 2012), but in other side Voght (2014) stated that ethnic difference had made local wisdom useful for development including in adapting to climate change. Then, Eid, et al (2011) explained human beings with different cultural, ethnic, and religious backgrounds share the globe and communicate together on interpersonal, organizational, and international levels.

In adapting climate change, Li and van Dijk (2012) classified into two categories namely passive and active. Passive category means people waits for government program. Meanwhile active category on traditional community uses govermental structures such as head of village o mobilize in supporting at village level. Active category on new community is by developing new community structure such as working 
together in functioning water basin. Meanwhile active category as individual is by having individual reaction such as alternative options in breeding animals, etc.

Meanwhile Johnson (2011) stated that form of adaptation consists of technological, operational, financial, sociological regulatory and administrative. Specifically, adaptation to climate change in fisheries could be categorized into autonomous and planned adaptation. Autonomous adaptation can be explained as changing the timing or locations of fishing as species arrive earlier/later or shift to new areas. Then, planned adaptation in fisheries may be research funding for finding species resistant to salinity and temperature fluctuations for aquaculture (Shelton, 2014).

\section{Methods}

This research was conducted in Masalembu Island Sumenep Regency East Java Province Indonesia. This location selected purposively because this island can be categorized as small island with area about 23.86 $\mathrm{Km}^{2}$ and has multi ethnic population (17,065 persons) consist of Madurese (74\%), Bugis (18\%), Mandar (7\%) and Javanese (1\%).

Primary data were collected by observation, indepth interview to the key informants i.e fisherman figures, ethnic figure, fish trader, religion figure and head of local government. Focus Group Discussion (FGD) and Rapid Rural Appraisal were conducted to improve primary data collection. Secondary data from local government and fisheries agency are necessary to support analysis.

There are two analysis methods in this study. They are descriptive quantitative analysis and qualitative analysis. Qualitative analysis consists of three paths of activity at the same time namely data reduction, display ad conclusion.

\section{Result and Discussion}

Masalembu islands is northeast island in Madura consisting of two villages namely Sukajeruk and Masalima village. Geographically Masalembu island is at $5^{\circ} 31^{\prime}$ latitude up to $5^{\circ} 35^{\prime}$ longitude. Masalembu island has $23,86 \mathrm{Km}^{2}$ in which size of Sukajeruk village is $11,77 \mathrm{Km}^{2}$ and size of Masalima village as wide as $12,09 \mathrm{~km}^{2}$. Meanwhile based on topography, as much as $3 \%$ or $1,23 \mathrm{Km}^{2}$ is hilly area with slope between $30 \%$ until $60 \%$ meanwhile $97 \%$ or area 39,26
$\mathrm{Km}^{2}$ is slope less than $30 \%$. Masalembu island is in Sukajeruk and Masalima Village.

Masalembu community is multiethnic consisting 17,065 peoples consist of Madurese (74\%), Bugis (18\%), Mandar (7\%) and Javanese (1\%). Most of Masalembu community depends on the sea. This is not surprising, as Ihsannudin (2012) explained that characteristic of small island mostly use land in agriculture and household industrial.

Peoples works in fisheries has high dependency on climate and weather (Ihsannudin, 2015). Therefore, climate change will affect livelihood of people relying on coastal and sea. Change felt by people in Masalembu island is fluctuate annual production result. This condition similar to findings of Herman, et al (2015) that climate change had caused unpredictable food production.

Table 1. Livelihood of Masalembu Community

\begin{tabular}{lc}
\hline Livelihood & Percentage (\%) \\
\hline Food Cultivation & 15.8 \\
Plantation & 11.1 \\
Livestock & 9.7 \\
Fisheries & 35.2 \\
Trading & 15.5 \\
Transportation & 2.3 \\
Household Industry & 2.9 \\
Craft & 1.1 \\
Services & 6.4 \\
\hline Total & 100 \\
\hline
\end{tabular}

Types of fishes catched by fishermen of Masalembu Island mostly consist of tuna, kite fish and mackerel. Fishermen use two types of traditional boat namely panyambalang boat with fish hook fishing gear and pajala boat with nets fishing gear. Besides, fishermen of Masalembu island use Fish Aggregating Devices/ FADs (rumpon). This rumpon is made from coconut leaves tied with holder rope and tied to bamboo. This is used to pull fish to gather in a point to make easier in catching fishes. Each fisherman has 2 to 3 rumpons on average. 


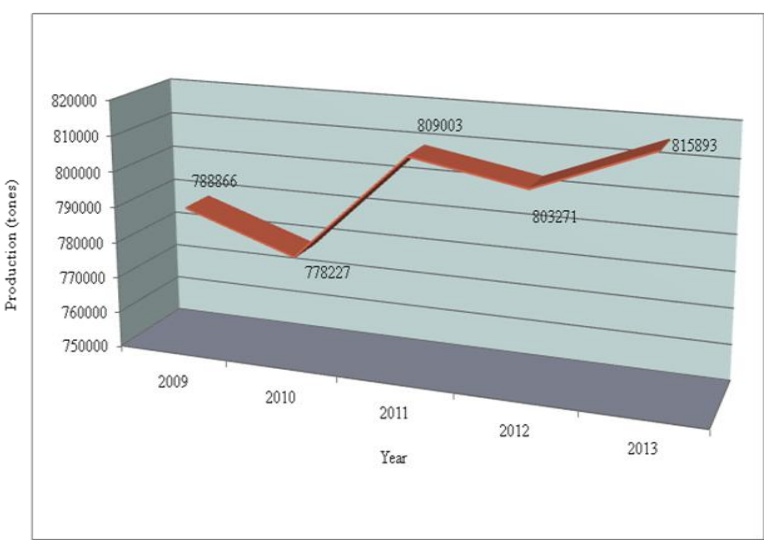

Figure 1. Fluctuation of Fish Production

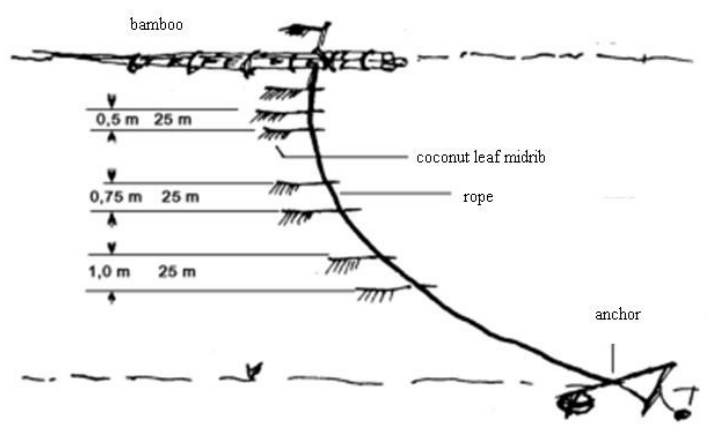

Figure 2. Fish Aggregating Devices/ FADs (rumpon)

At this time, income achieved by fishermen of Masalembu is averagely $16,384,770,-$ IDR per year or $1,365,397.5$ IDR per month. This income had been reduced by costs for fishing such as fuel, supplies and fishing gear properties. This distinguished finding of Zajmi (2012) that climate change has serious impact on economic growth of area.

Then, negative impact felt by fishermen in Masalembu is extending fishing ground to be more off shore. This is cause by fishermen difficult to obtained huge number of fishes close to the land. Similarly, rumpon that placed close to the land only there are a few fish. In the past, fishermen of Masalembu only explored and placed rumpon by the range 10 -15 miles, then this change into $20-30$ miles from coastline. This implicate on that as increase of costs spent by fishermen.

Impact of climate change is uncertain fishing schedule. This is caused by uncertain high wave and winds. Climate change has a great impact on gravitation, ice melting, sea over flow and change of weather (Bhattacharjee, 2010). Basically, fishing phase of Masalembu divided into low season, peak season and middle season. There is information gained that it has been fixed before that entering January to April is low season phase, April to July is peak season,
July to October is middle season and October to December is low season phase. But recent times the phase has been uncertain condition. This finding is similar to Daw, et al (2009) stated that climate change will impact on fisheries that difficult to be predicted.

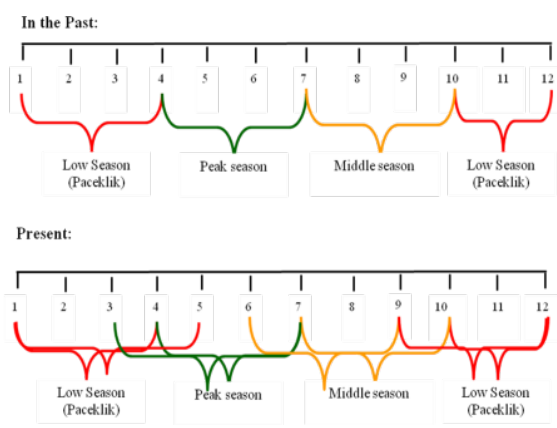

Figure 3. Uncertainty Schedule for Fishing

Climate change is felt by fishermen in outside of Masalembu island such as Java island. Therefore, they also expand until Masalembu area. Generally, fishermen from outside islands area such as East Java and Central Java used boat with high capacity and modern fishing gear as well as application of storage system. Ironically there are many unfriendly fishing gears such as trawl. Actually, regulation in Indonesia arranged in Regulation of Marine and Fisheries Number 2 / Permen-KP/ 2015 stated that trawl and seine net is forbidden to be used in Indonesia.

Outsider fishermen coming with modern fishing gear and unfriendly fishing gear had cause huge fish catching in Masalembu island. Fishing gear of outsider fishermen often times damage rumpons belongs to Masalembu fishermen. This caused decrease of fish amounts in Masalembu. If compare to boat and fishing gear of outsider fishermen, Masalembu fishermen still use traditional boat and fishing gear.

Result of study showed that fishermen in Masalembu island had conducted active adaptation to climate change. Active behavior of masalembu island fisherman is by developing structure of fishermen groups in Masalembu. This group is seen in the effort of preventing utilization of unfriendly fishing gear both from Masalembu or out area of Masalembu. Recently, there have been group of Masalembu's fishermen arrest fisherman's boats from Central Java that fishing in Masalembu area by using unfriendly fishing gear and damage fishermen's rumpon. Fisherman boats from Central Java then being arrested to be asked for responsible due to damage of 
Masalembu fishermen rumpon. Although the case become complicated and opinion developed into hostage of central java fisherman's boat by Masalembu fishermen. Actually, Masalembu fishermen requested for responsibility of central java fishermen for damage of rumpon.

Groups of fishermen in Masalembu also playing the role in institutionalize or facilitate and administration function of any aids from government in fisheries field. Aids of government are fishing gear and assistance in gropuss as well as fish processing. If there is good collaboration between NGO and government then it is proved that this can run development program held by government (Makondo, et al. 2014).

Meanwhile fishermen behavior of Masalembu next will change fishing time and location (autonomous adaptation). Masalembu fishermen try to find fish spots although the location is far from land. In order to efficient operational cost, Masalembu fishermen go for fishing a week eventhough usually only takes fishing time start in morning and go home in the evening. In fact, perform aquaculture activities (planned adaptation) need to be carried out by fishermen Masalembu. This is important in responding climate change to defend livelihood (Allison, et al. 2007; William and Rota, 2009).

Technology adoption has been done by fishermen of Masalembu in adapting climate change. GPS (Global Positioning System) is generally used by masalembu fishermen to determine fishing coordinat and remark position of rumpon. Similar thing mentioned by Bolong, et al (2013), mobile phones emerged as the most-used piece of ICT equipment among young fishermen, followed by GPS and echo sounders. Masalembu's fishermen also build more rumpon to be more pull fish in certain spot.

Sociologically Masalembu fishermen conduct sharing resources on rumpon or known as nyampa. It means that a fisherman can fishing on other fishermen rumpons after the owner do fishing. Even more if already having the permit, a fisherman can fish on other fishermen rumpon although the owner has not fishing yet. This activity does not involve any ethnic, which means that every ethnic may do this among Madurese and Bugis or Madurese with Mandar, or even Mandar with Bugis. This is important of community participation in facing climate change effect (Belachew, et al, 2015)
Masalembu fishermen that administratively helped by village government make rule that it is forbidden to fishing by unfriendly fishing gear such as poison, bomb and trawl. Masalembu fishermen does not make any difference on ethnic, who being proven doing these forbidden activities will get social and fine. The fact that fishermen proven to break the rule respects the sanction altough they come from different etnic. Fishermen institution had also make unwritten deal (convention) with outsider fishermen for not fishing in the range 30 miles of land, not using unfriedly fishing gear and fishing on rumpons belongs to masalembu fishermen. This is important for the environment that may affect people prosperity (Sundah, 2013).

Gratitude to Directorate of Research and Services DIKTI Ministry of Research and Higest Education Republik of Indonesia that had funded this research through PEKERTI research scheme. It also delivered to government of Masalembu Sub-District Island that had facilitated the research.

\section{Conclusion}

Negative effects of climate change for multi ethnic in small island are fluctuative production of fish production, extending fishing ground to be more off shore, uncertainty schedule for fishing and Outer fisherman with modern and unfriendly environmentally fishing gear (from central java) come to this island. Multiethnic fisherman behavior in adapting climate change is by having active behavior in developing fisherman structure to prevent unfriendly fishing gear, and also doing administrative function due to aids of government. In addition, there is also autonomous role by changing fishing time and location. As the last, multiethnic fishermen also apply adaptation behavior technologically, sociologically and regulatory. Base on study, it is recommended to do planned adaptation through aquaculture, applying modern but friendly technology fishing gear and also enhancing participation as well as cooperation among fisherman without ethnic consideration in small island.

\section{References}

Agrawal, Arun. 2008.The Role of Local Institution in Adaptation to Climate Change. Paper. Social Dimensions of Climate Change, Social Development Department, 
The World Bank, Washington DC, March 56, 2008

Ajao, AO and Ogunniyi, LT. 2011. Farmer's Strategies for Adapting to Climate Change in Ogbomoso Agricultural Zone of Oyo State. Agris on-line Papers in Economics and Informatics Vol III Number 32011

Allison, Edward H. Andrew, Neil L. Oliver, Jamie. 2007. Enhancing the Resilience of Inland Fisheries and Aquaculure System to Climate Change. SAT eJournal. December. 2007 Vol 4 Issue 1

Badjeck, Marie-Caroline. Allison, Edward, H. Hall, Assley, S and Dulvy, Nicholas K. 2010. Impacts of Climate Variability and Change on Fishery-Based Livelihood. Marine Policy 34 (2010) 375-383

Belachew, Olika. Zuberi, Muhammad, Iqbal. 2015. Perception of Climate Change and Livelihood of A Farming Community of Maruf Kebele, Central Oromia, Ethiopia. American Journal of Climate Change, 2015, 4, 269-281

Bhattacharjae, Pijush, Kanti. 2010. Global Warming Impact on The Earth. International Journal of Environmental Science and Development, Vol 1 No 3 August 2010

Bolong, Jusang. Omar, Siti, Zobidah. D'Silva, Jeffrey, Lawrence. Shaffril, Hayrol, Azril, Mohammed and Hasan, Musa, Abu. 2013. ICT Utilisation and Its Impact on the Income of Young Fishermen in Malaysia. Pertanika J. Soc. Sci \& Hum 21 (S) 49-58 (2013).

Briguglio, L. 1995. Small Island Developing State and Their Economic Vulnerabilities. World Development, 23 (9), 1615-1632.

Daw, Tim. Adger, W, Neil. Brown, Katrina and Badjeck, Marie-Caroline. 2009. Climate Change and Capture Fisheries: Potential Impact, Adaptation and Mitigation. Paper. FAO Fisheries and Aquaculture Technical. Rome

Eid, Mahmoud. Saferty, Isaac Nahon and Ahmed, Rukhsana. 2011. Multi-Cultural, MultiEthnic and Multi Faith Communication. Global Media Journal Vol 4 Issue 1 pp 1-4
Herman, Tiara. Murchie, Erik H. Warsi, Asgar, Ali. 2015. Rice Production and Climate Change: A Case Study of Malaysian Rice. Pertanika J. Trop. Sci 38 (3): 321-328 (2015)

Hossain, MS. Rahman, MS. Thompson, S. Nabi, M.R. Kibria, M.M. 2013. Climate Change resilience Assessment Using Livelihood Assets of Coastal Fishing Community in Nijhum Dwip Bangladesh. Pertanika J. Sci and Technology 21 (2): 397-422 (2013)

Ihsannudin, 2012. Feasibility Analysis of Fish Meat Ball for Economic Development of Small Island Community. Proceeding. National Conference of Developing of Food Defence Based on Local Heritage to Support People Economic. September 12, 2012. Mercubuana University. Yogyakarta. Indonesia

Ihsannudin. 2015. The Role of Social Capital On Salt Smallholder Society Of Madura Indonesia In Land Certification Ownership. Scientific Journal of PPI-UKM Vol 2 No. 5. 2015. 144-151

Johnson, Terry. 2012. Fisheries Adaptation to Climate Change. Working Paper. University of Alaska Fairbanks. Fairbanks

Kasperson, Roger,E and Kasperson, Jeanne, X. 2001. Climate Change, Vulnerability and Social Justice. Stockholm Environment Institute. Stocholm Sweden

Li, Hao and van Dijk, Maine Pieter. 2012. Climate Change and Farmer Responses in Rural

China. Int J. Water Vol 6 Nos 3/4, 2012

Makondo, Cuthbert, Casey. Chola, Kenneth and Moonga, Blesswell. Climate Change Adaptation and Vulnerability: A Case Rain Dependent Small Holder Farmer in Selected District in Zambia. America Journal of Climate Change, 2014, 3, 388-403

Mohanty, Manoranjan. 2006. Squatters, Vulnerability and Adaptability of Urban Poor in a

Small Island Developing State: The context of Fiji Islands', Paper. Presented at International Geographical Union Commission (IGU) Conference on Population and Vulnerability, 3-7 July, 2006, Brisbane, Australia 
Morduch, Jonathan. Poverty and Vulnerability. The American Economic Review Vol. 4 No 2, 221-225

Muhsoni, F.F. 2006. Assessment of Fish Resources In The Madura Strait Using Holistic Method and it Economic Analysis. Embryo Vol 2 No 3.

Shelton, Clare. 2014. Climate Change Adaptation in Fisheries and Aquaculture Compilation of Initial Example. FAO. Rome

Suadi and Nakagawa, Mitsuhiro, 2009. Sharing the Commons: Resolving the Tragedy of the

Commons through Collaborative Management of Coastal Commons at Kedonganan Village, Bali. Journal of Kyosei Studies 3(1): 263285.

Subejo, 2008. Promoting Social Capital For Rural Community Development. Jurnal IlmuIlmu Pertanian Vol 4 No. 1 juli 2008

Subejo, 2009. Characteristics and Functions Of Labor Institutions In Rural Java: A Case Study In Yogyakarta Province. Journal of the International Society for Southeast Asian Agricultural Science (ISSAAS) Vol.15 No.1 (June 2009): 101-117

Sundah, Daisy I.E. Suman, Agus. Soemarno. Kindangen, Paulus. 2013. How Coastal Development, And Adaptive Behaviour Affect Fishermen's Welfare?: (Study Traditional Fishermen From The Coastal
Area of Manado Bay, Indonesia. IOSR Journal of Humanities and Social Science Vol 17, Issue 4 (Nov - Dec. 2013), PP-2434

Suntoo, Rajee and Chitoo, Hemant, B. 2012. Managing Multi-Ethnic Mauritius. Global Journal of Human Social Science Vol 12 Issue 3 version 1.0 February 2012

Tisdell, Clem. 2006. Economic Prospect for Small Island Economies, Particularly in the South Pacific, in Globalising World. Working Paper. The University of Queensland

Turner, Rachel, A. Polunin, Nicholas VC, Stead, Selina, M. 2014. Social Network and

Fisheries Behaviour: Exploring the Link Between Information Flow and Fishing Success in The Northumberland Lobster Fishery. Ecology and Socity 19 (2): 38

Voght, Manuel. 2014. Ethnic Mobilization, Equality and Conflict in Multi Ethnic State. Working Paper. Swiss National Science Foundation. Zurich

Williams, Leon and Rota, Antonio. 2009. Impact of Climate Change on Fisheries and Aquaculture in The Developing World and Opportunities for Adaptation. Fisheries Tematic Paper. Rome

Zajmi, Sandra. 2012. Adapting of Economic Development to Climate Change. Journal of Economic Development, Environment and People Vol. 1 Issue 2 